\title{
DIE VERPLEEGSTER SE TERAPEUTIESE FUNKSIE
}

\author{
deur \\ D.C. Harrington, \\ B.A. (Verp.) M.Cur. (Int. Alg. Verpl.) Pretoria \\ M.E.C. Potgieter, \\ B.Cur., M.Cur., (Int. Alg. Verp.) Pretoria
}

Oorgedruk uit Geneeskunde, Maart 1979, welwillend afgestaan deur die Redakteur.

$\mathbf{O}$ ns sou hierdie praatjie graag wou inlei met Virginia Henderson se definisie van verpleging: "The unique function of the nurse is to assist the individual, sick or well, in the performance of those activities contributing to health or its recovery (or to a peaceful death) that he would perform unaided if he had the necessary will, strength or knowledge. And to do this in such a way as to help him gain independence as rapidly as possible."'

By verpleging val die klem op die ondersteuning van die individu eerder as op behandeling van die siektetoestand as sodanig. Volgens Moidel moet pasiëntsorg bereik word d.m.v. doelbewuste sistematiese en geïndividualiseerde verplegingsoptrede. Hierdie optrede kan verdeel word in verskeie basiese komponente, nl.:
- sorg
- herstel
- koordinasie
- raadgewing
('care')
('cure)
('co-ordination')
('counselling')

Die versorgingsfunksie is daardie onafhanklike verplegingshandelinge wat lei tot ' $n$ afname in fisiese en psigiese spanning by die pasiënt en die bevordering van gemak.

Die herstelfunksie, vanweë die feit dat dit 'n mediesvoorgeskrewe of gedelegeerde funksie is, omvat die afhanklike funksies van die verpleegster, bv. bystand met die uitvoer van 'n omvattende mediese ondersoek. In verskillende situasies $k$ an die verpleegster se funksie wissel van afhanklik na onafhanklik. ${ }^{2}$

Die derde funksie is die koördinasie van pasiëntsorg wat op sy beurt drieledig onderverdeel word, $\mathrm{nl}$.:

(a) sinkronisering van verskillende terapieë, toetse en dienste om sodoende kontinuilteit van sorg te verseker;

(b) samewerking met ander lede van die gesondheidspan, wat 'n invloed kan hê op die manier waarop hulle die pasiënt in hul onderskeie afdelings versorg;

(c) samewerking met andere in onderrig aan sowel pasiënt as naasbestaandes en in die beplanning en uitvoering van behandeling. ${ }^{3}$

Om goeie koördinasie tussen die verskeie aspekte van pasiëntsorg te verkry, is kommunikasie essensieel. Uit kommunikasie wat op skrif gestel en vir die onderskeie lede van die gesondheidspan toeganklik is, sal beter kontinuiteit vir dienslewering voortvloei. Omdat die verpleegster vergelykenderwys vir lang periodes by die pasiënt is en verpleegsorg 24 uur per dag gelewer word, oorvleuel die rol van die verpleegster onvermydelik en dikwels met dié van ander professies.
Soos dr. J.A.M. Greay ${ }^{4}$ dit stel: dokters het te doen met siektetoestande in mense, en maatskaplike werkers met verhoudingsprobleme 'om' mense. Die verpleegster, egter, behandel siektetoestande by mense, versorg hulle tydens siekte en het die bepaalde rol om die persoon te help om die veranderde verhouding wat hy vanweë die siektetoestand met homself het, te verwerk. ${ }^{4}$

Vierdens behels verpleging raadgewing en onderrig aan pasiënte. Jean Crow sê in 'n bespreking van Henderson se definisie van verpleging dat die woorde "krag", "wil" en "kennis" die verpleegster se drievoudige rol as fisiese helper, emosionele ondersteuner en onderriggeefster dek. Die definisie beklemtoon onafhanklikheid eerder as herstel, wat die realistiese siening behels dat die mens, hoewel onbekwaam om alles te genees, nog sy onvermoë kan oorbrug en onafhanklik kan bly. ${ }^{5}$

Verpleegsters moet dus aanspreeklik wees nie net vir wat hulle doen nie, maar ook vir hoe hulle dit doen. Die verpleegster moet die pasiënt se emosionele, geestelike en fisiese behoeftes bepaal, bv. hoe hy sy siekte, die behandeling en die prognose ervaar. Toegerus met hierdie inligting en die vermoë om met mense in voeling te tree, is die verpleegster in staat om aan die pasiënt raad en onderrig te gee.

Vervolgens 'n uiteensetting van hoe die verpleegster hierdie funksies sinvol en wetenskaplik d.m.v. die verpleegproses kan verrig:

- eerstens moet sy die pasiënt se behoeftes bepaal;

- tweedens moet sy ooreenkomstig haar bevindinge doelstellings formuleer, prioriteite stel en optrede beplan;

- derdens moet sy die plan implementeer;

- laastens moet sy haar optrede n.a.v. die uitwerking wat dit op die pasiënt se behoeftes gehad het, evalueer.

Nancy Kelly" het in 1966 gesê: "Nurses have always planned patient care but today when a hospitalised patient is transferred through a series of specialised departments in the course of his treatment, and his daily care is divided between both professional and auxiliary nursing personnel, continuity of care is possible only when a patient's needs are first analyzed and then written down in detail in a nursing care plan."'6

Vir elke pasiënt behoort daar 'n verpleegsorgplan te wees, gebaseer op sy persoonlike voorkeure, verwagtings, behoeftes en probleme. So 'n plan sal verpleegoptrede wat op die bepaalde individuele 
behoeftes afgestem is, aanbeveel, en sal skriftelike evaluering van die effektiwiteit van die verpleegaksie insluit.

Behoeftes kan biologies, psigies of sosiaalkultureel wees. 'n Vorm met standaardopskrifte soos die volgende sal verseker dat al die aspekte van pasiëntsorg sistematies gedek is:?

1. Persoonlike gegewens

2. Die pasiënt se waarnemings en verwagtings met betrekking tot sy siektetoestand en hospitalisasie

3. Spesifieke basiese behoeftes:

Volgens Crow ${ }^{5}$ is die doel van die vrae onder hierdie opskrif die volgende:

(a) om die pasiënt se normale daaglikse lewensaktiwiteite vas te stel;

(b) om enige veranderinge wat nodig is in die bg. aktiwiteite te beperk;

(c) om die pasiënt te onderrig en ondersteun met die implementering van enige permanente veranderinge;

(d) om die pasiënt se veiligheid te verseker, sowel in die hospitaal as tuis.

Basiese behoeftes wat in ag geneem behoort te word is:

i gemak, insluitend rus en slaap, persoonlike higiëne, kleredrag en bekamping van pyn

ii veiligheid, muskuloskeletale beperkings, visuele of gehoorafwykings, en gewoontes soos rook, wat $n$ potensiële medies-geregtelike risiko kan wees, moet aandag kry

iii voeding

iv eliminasie-gewoontes

$\checkmark$ vitale funksies

4. Sosiale en interpersoonlike gegewens

5. Geestelike behoeftes

Die verpleegsorgplan behoort ook 'n raamwerk van die beplande mediese sorg in te sluit omdat baie verpleegaktiwiteite op mediese behandeling gebaseer is. ${ }^{8}$

Naas kommunikasie met die pasiënt worá waarneming en diagnostiese tegnieke soos elektrokardiografie, röntgenografie ens. gebruik om gegewens te verkry. Daarna moet die gegewens geanaliseer word en die pasiënt se verplegingsbehoeftes geidentifiseer word. ${ }^{9}$.

Dit bring ons by die tweede stap in die verpleegproses, nl. die formulering van die verpleegdoelwit en die beplanning van verplegingsoptrede. Little en Carnavalito beweer dat, nadat die pasiënt se behoeftes bepaal is, die volgende stap is om prioriteite vir aandag en sorg te stel. Hier kan Maslow se hierargie van die mens se fundamentele behoeftes in berekening gebring word, $\mathrm{nl} .:^{10}$

(self-actualization)

5 selfverwesenliking

(esteem)

4 agting

(beloning)

3 liefde

(safety)

2 veiligheid

(physiological needs)

1 fisiese behoeftes
Mayers (1972) verdeel probleme in 3 kategorieë:

1. Werklike probleme nl. dié wat op 'n gegewe tyd geidentifiseer kan word.

2. Potensiële probleme nl. die wat maklik kan voorkom maar wat verhoed kan word deur voorafbeplande verplegingsoptrede.

3. Moontlike probleme $\mathrm{nl}$. diè wat nie d.m.v. die beskikbare gegewens duidelik geidentifiseer kan word nie. Verdere inligting word benodig voordat besluit kan word of dit werklike of potensiële probleme is. ${ }^{11}$

Deur bepaling van 'n pasiënt se behoeftes word die nodige data bekom om die beplanning van die verpleegsorg te verpersoonlik. Erkenning van die pasiënt se voorkeure gedurende die beplanning is een metode om die verlies van identiteit wat met hospitalisasie gepaard gaan, te beperk. ${ }^{12}$ As ' $n$ pasiënt bv. in staat is om homself te bad, behoort hy aangemoedig en toegelaat word om te besluit of hy soggens of saans wil bad.

Nadat die verplegingsdoelwit gestel is, is die volgende stap die implementering van die plan om hierdie doelwit te bereik. Volgens Eckelberry sluit implementering van die verpleegsorgplan keuring en gebruik van beide menslike en materiele hulpbronne in wat sal help om die doelwit te bereik. Die menslike hulpbronne sluit die gesin, maatskaplike werker, geestelike raadgewer en so meer in. Dit is belangrik dat sowel die pasiënt as sy gesin betrek word by die keuse van daardie hulpbronne. ${ }^{13}$

Die bg. optrede omvat al die dienste wat die pasiënt help om te voorsien in die behoeftes wat geîdentifiseer is en wat hy nie sonder hulp kan bevredig nie. Terwyl sy sorg verleen, verkry die verpleegster bykomende gegewens wat haar help om vas te stel of die optrede werklik die pasiënt se behoeftes bevredig. Dit kan ook lei tot ' $n$ herbepaling van die pasiënt se behoeftes.

Alhoewel evaluering beskou word as die laaste stap in die verpleegproses moet dit deurlopend gedoen word om foute onmiddellik of so gou moontlik reg te stel en herhaling daarvan te voorkom. Fisiese veranderinge en verbetering is relatief maklik om te evalueer, bv. daling van liggaamstemperatuur na afsponsing met lou water. Probleme ontstaan egter wanneer daar gepoog word om te bepaal wat die oorsaak van veranderde psigososiale gedrag is. Verskeie skrywers, insluitend Eckleberry, ${ }^{14}$ siel voor dat pasiënte se gedra eerder in detail beskryf word as dat nikssegende veralgemenings soos 'verbetering in houding' of 'minder angstig' gebruik word.

Die pasiënt behoort ook betrek te word by die evaluering van die verpleegsorg. Die effek van optrede om pyn te verlig kan die beste deur die pasiënt self bevestig word. Soms kan gesinslede en ander lede van die gesondheidspan hul bydrae lot die evaluering van die verplegingsoptrede lewer, bv. wanneer die pasiënt vir behandeling verwys word na ander afdelings waar die verpleegster self nie vir observasie teenwoordig is nie.

Vervolgens 'n kort samevatting van hoe die verpleegproses $n$ die geval van 'n pasiënt met miokardiale infarksie geimplementeer kan word. 
Tabel 1: Implementering van die Verpleegproses by 'n Pasiënt met Miokardiale Infarksie

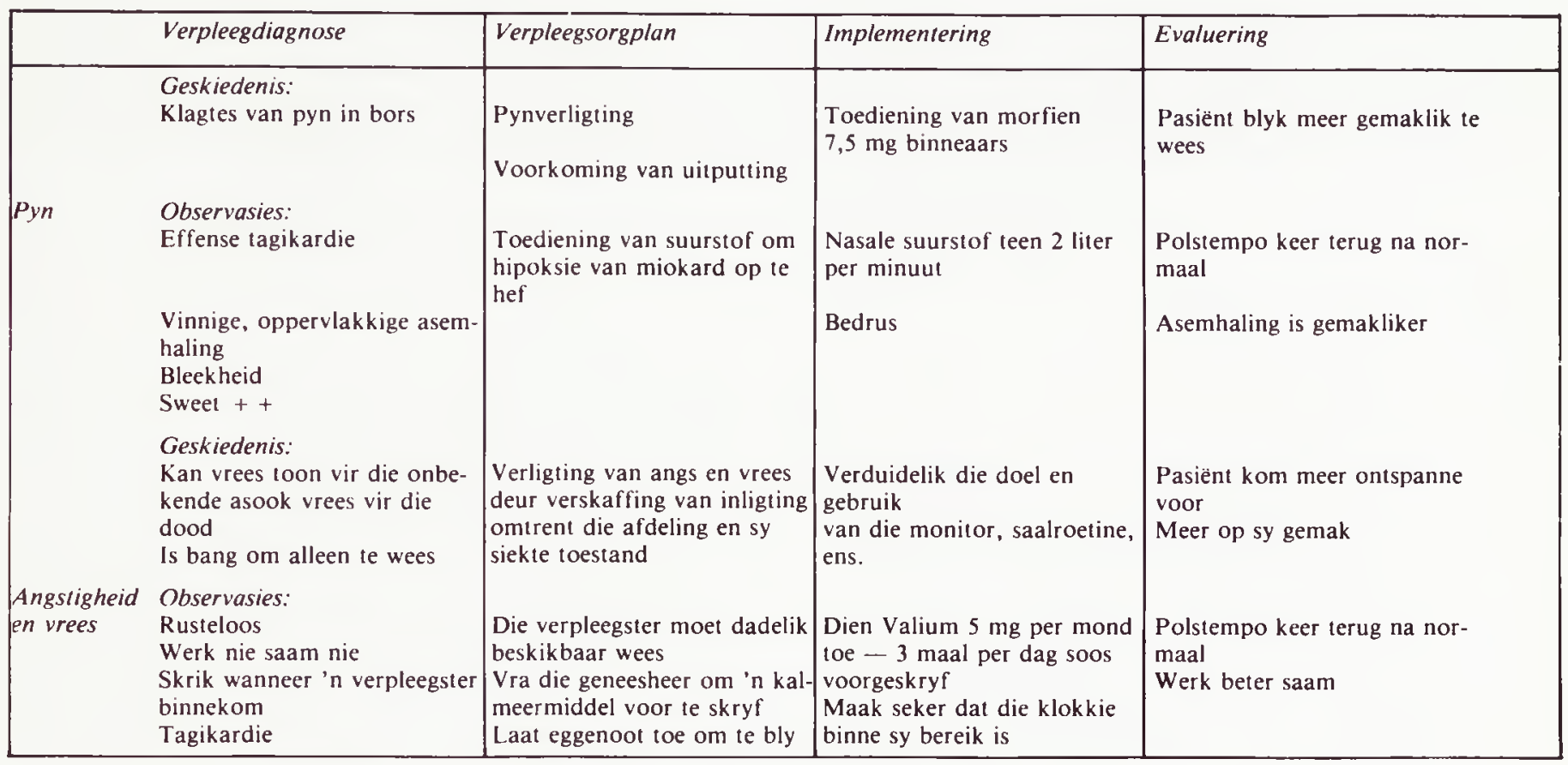

Samevattend wil ons dit graag beklemtoon dat die bg. benadering gebruik kan word as instrument om verpleegsorg te verbeter en dat dit so ook grotér werkbevrediging vir die verpleegster kan lei; meer nog, dat dit die pasiënt in staat stel om beter toegerus van sy siekte te herstel tot so 'n vol lewe as moontlik, of om die dood met kalmte en vrede tegemoet te gaan. ${ }^{15}$

\section{VRRUYLINGs}

1. Henderson, V. Basic Principles of Nursing Care, bl.4, New York, S. Karger Basal, 1969
2. Moidel, H. el al Nursing Care of the Patient with Medical Surgical Disorders, $2 \mathrm{e}$ uitgawe, bl.7, McGraw Hill, 1976.

3. Little, D. en Carnevali, D.L. Nursing Care Planning, bl.8, Philadelphia, Lippincott, 1969

4. Gray, J.A.M. Nursing Mirror, 1977, 145, 12

5. Crow, J. Nursing Times, 1977, 73, 895

6. Kelly, N.C. Nursing Outlook, 1966, 14,61

7. Henderson, V. Gp. til., bl.63 Garant, C. McPhetridge, L.M. Amer. Journ. of Nurs. 1968, 68, 71. Amer. Journ, of Nurs., 1968, 68, 71

8. Kelly, N.C. Op. cit., bl. 956

9. Lewis, 1. Nursing Outlook, 1968, 16, 28

10. Little, D.E. en Carnevali, D.L. Op. cit., hl. 54

11. Crow, J. Gp. cit. bl. 892

12. McPhetridge, L.M. Op. cit., bl.7

13. Eckelberry, G. Administration of Comprehensive Nursing Care, bl. 101, New York, Appelton Century Crofts, 1971

14. Ibid, bl. 86, 107

15. Lewis, L. Cp. cil., bl.29 